\title{
Studi karakteristik habitat peneluran penyu di desa pekik nyaring Kecamatan Pondok Kelapa Kabupaten Bengkulu Tengah, Provinsi Bengkulu
}

\author{
(Study of the characteristic of sea turtle nesting area in Pekik Nyaring Village, \\ Pondok Kelapa District, Central Bengkulu Regency, Bengkulu Province)
}

\author{
${ }^{1}$ Roni Setiawan, Zamdial dan Bertoka Fajar SPN \\ ${ }^{1}$ Program Studi Ilmu Kelautan, Fakultas Pertanian, Universitas Bengkulu \\ e-mail : zamdial_et@yahoo.co.id
}

\begin{abstract}
ABSTRAK
Salah satu lokasi tempat penyu mendarat dan bertelur di Provinsi Bengkulu adalah di pantai Desa Pekik Nyaring, Kecamatan Pondok Kelapa, Kabupaten Bengkulu Tengah. Mengingat penyu adalah satwa langka yang dilindungi, maka perlu dilakukan kegiatan konservasi untuk melindungi dan menyelamatkan penyu. Untuk mendukung upaya konservasi perlu mempelajari lokasi-lokasi tempat penyu bertelur. Seperti halnya penelitian terhadap lokasi pendaratan dan tempat penyu bertelur. Tujuan penelitian ini untuk menganalisis tingkat kesesuaian karakteristik kondisi bio-fisik habitat tempat peneluran penyu di wilayah pantai Desa Pekik Nyaring. Penelitian ini dilaksanakan pada bulan Februari-Mei 2017 dengan menggunakan metode survei. Kegiatan survei meliputi observasi lapangan dan pengumpulan data primer. Analisis data dilakukan dengan metode statistik deskriptif. Berdasarkan hasil observasi dapat diketahui bahwa jenis penyu yang bertelur di pantai Desa Pekik Nyaring adalah jenis penyu lekang (Lepidochelis olivácea). Hasil analisis data menunjukkan bahwa, panjang pantai yang menjadi lokasi peneluran penyu adalah $1,47 \mathrm{~km}$, lebar pantai adalah 99,9 - $170 \mathrm{~m}$, kemiringan pantai 2,22\%$30,85 \%$, suhu substrat $28^{\circ} \mathrm{C}-28,66^{\circ} \mathrm{C}$, kelembaban substrat $28,77 \%-40,44 \%$. Untuk tekstur substrat, pada semua stasiun termasuk dalam kategori halus, sedangkan persentase vegetasi pantai $22,3 \%-60,3 \%$. Dari ketiga stasiun pengamatan, stasiun 1 dan 2 cukup sesuai, sedangkan stasiun 3 masuk kategori tidak sesuai sebagai lokasi peneluran penyu.
\end{abstract}

Kata kunci : Penyu, karateristik, tempat bertelur, Pekik Nyaring, Bengkulu

\begin{abstract}
One of the locations where sea turtles landed and nesting in Bengkulu Province is at beach of Pekik Nyaring Village, Pondok Kelapa District, Central Bengkulu Regency, Bengkulu Province. Considering that sea turtles are endangered species, conservation activities are needed to protect and save turtles. To support conservation efforts, it is necessary to study of various locations of turtels nesting area. As wel as research on landing sites and turtles nesting area. The purpose of this study was to analyze the suitability level of bio-physical conditions characteristic of nesting area location in coastal areas Pekik Nyaring Village. This research was conducted in February-March 2017 using survey method. Survey activities include filed observation and collection of primary data. Data analysis is done by descriptive statistic method. Based on the observation result can be seen that the type of sea turtle that is nesting on the beach of Pekik Nyaring Village is a type of Penyu lekang (Lepidochelis olivácea). The results of data analysis show that the length of the beach that is the location of sea turtles nesting area $1.47 \mathrm{~km}$, the wide of beach were 99.9-170 $\mathrm{m}$, beach slope average were 2,22\% - 3 $0,85 \%$, substrate suhue were $28{ }^{\circ} \mathrm{C}-28,66{ }^{\circ} \mathrm{C}$, substrate humidity were $28,77 \%-40,44 \%$. For substrate texture on all station including the subtle category, while the percentage of coastal vegetation is 22.3\%-60.3\%. From the three observation stations, stations 1 and 2 are quite appropriate, while station 3 is not suitable for turtle nesting area.
\end{abstract}

Keywords : Turtles, characteristic, nesting area, Pekik Nyaring, Bengkulu 


\section{Pendahuluan}

Penyu termasuk hewan yang terdaftar dalam CITES (Convention on International Trade in Endangered Species of Wild Fauna and Flora) atau konvensi perdagangan internasional tumbuhan dan satwa liar spesies terancam adalah perjanjian internasional antar negara yang disusun berdasarkan resolusi sidang anggota World Conservation Union tahun 1963. Spesies ini masuk daftar merah IUCN (2008) dan dilindungi berdasarkan SK Menteri Pertanian No.716/Kpts/10/1980 dengan status proteksi dan berdasarkan PP No.7 tahun 1999 tentang pengawetan jenis tumbuhan dan satwa serta PP No.8 tahun 1999 tentang pemanfaatan jenis tumbuhan dan satwa liar. Penyu laut merupakan reptil yang hidup di laut serta mampu bermigrasi dalam jarak yang jauh di sepanjang kawasan Samudera Hindia, Samudra Pasifik dan Asia Tenggara (Fitriyanti, 2006 dalam Yulmeirina et al., 2016). Kekayaan alam Indonesia berupa terumbu karang, padang lamun dan pantai berpasir merupakan habitat alami yang sangat baik bagi kelangsungan hidup penyu (Indra, 2010 dalam Ageng et al., 2013). Dahuri (2003) mencatat lebih kurang 143 lokasi peneluran penyu yang tersebar di seluruh Indonesia.

Provinsi Bengkulu dengan panjang garis pantai $\pm 525 \mathrm{~km}$ (Bappeda Provinsi Bengkulu, 2016), memiliki pontensi tempat pendaratan penyu yang cukup bagus. Perairan laut Provinsi Bengkulu juga memiliki keragaman hayati ekosistem pesisir berupa terumbu karang, padang lamun dan rumput, yang diketahui menjadi habitat penyu laut. Provinsi Bengkulu terdiri dari 10 kabupaten/kota, dimana 7 kabupaten/kota berada di sepanjang Pantai Barat Pulau Sumatera. Salah satu kabupaten yang menjadi tempat penyu mendarat dan bertelur adalah Kabupaten Bengkulu Tengah. Walaupun Kabupaten Bengkulu Tengah hanya memiliki panjang garis pantai $\pm 28,5 \mathrm{~km}$ (Bappeda Kabupaten Bengkulu Tengah, 2013), namun sepanjang kawasan pantai Desa Pekik Nyaring, Kecamatan Pondok Kelapa diketahui sejak lama sebagai tempat penyu mendarat dan bertelur. Sebagai kawasan tempat pendaratan dan peneluran penyu, kondisi kawasan pantai Desa Pekik Nyaring juga sudah memprihatinkan. Saat ini kawasan pantai tersebut terus mengalami abrasi dan terdapat sampah-sampah seperti plasik dan kayu karena pengaruh gelombang dan angin laut yang mengakibatkan pantai terlihat kotor. Adanya aktifitas nelayan yang menggunakan kawasan pantai untuk berbagai kegiatan, terutama sebagai sentra perikanan tangkap, dimana hal ini menjadi ancaman terbesar bagi penyu yang akan melakukan pendaratan untuk bertelur.

Mengingat potensi kawasan pantai yang menjadi tempat mendarat dan bertelurnya penyu, serta adanya kawasan yang mengancam penyu-penyu tersebut, maka nelayan dan warga setempat mempunyai inisiatif untuk melakukan kegiatan pelestarian penyu dengan membentuk Kelompok Pelestari Penyu Alun Utara. Pelestarian penyu telah dilakukan oleh kelompok dengan menetaskan telur penyu, walaupun pada awalnya gagal dalam masa inkubasi (masa penetasan), karena kurangnya pengalaman dan ilmu kelompok pelestari penyu tersebut. Salah satu faktor kehadiran penyu ke pantai dipengaruhi kondisi bio-fisik pantai yang sesuai untuk peneluran penyu. Secara biologi kehadiran penyu pada suatu pantai dipengaruhi kondisi sebaran ekosistem dan komposisi vegetasi pantai, sedangkan keberadaan hewan predator akan mempengaruhi tingkat jumlah telur penyu dan tukik. Untuk mendukung upaya konservasi penyu di Desa Pekik Nyaring maka perlu diadakan kajian karakteristik kondisi bio-fisik pantai sebagai tempat penyu bertelur antara lain, kemiringan pantai, lebar dan panjang pantai, kadar air, dan komposisi butiran pasir pantai. Adapaun kondisi biologis yang perlu 
diperhatikan antara lain jenis vegetasi yang mendominasi di pantai peneluran dan disukai oleh penyu sebagai lokasi pembuatan sarang (Yayasan Alam Lestari, 2000).

\section{Metodologi penelitian}

\subsection{Waktu dan tempat penelitian}

Penelitian ini dilakukan pada bulan Februari-Mei Tahun 2017 di Pantai Pekik Nyaring Kecamatan Pondok Kelapa Kabupaten Bengkulu Tengah Provinsi Bengkulu (Gambar 1). Lokasi penelitian ini berjarak $\pm 15 \mathrm{~km}$ dari Kota Bengkulu (ibu kota Provinsi Bengkulu) dan berada pada lintasan jalan raya Pantai Barat yang mengubungkan Provinsi Bengkulu dengan Provinsi Sumatera Barat.

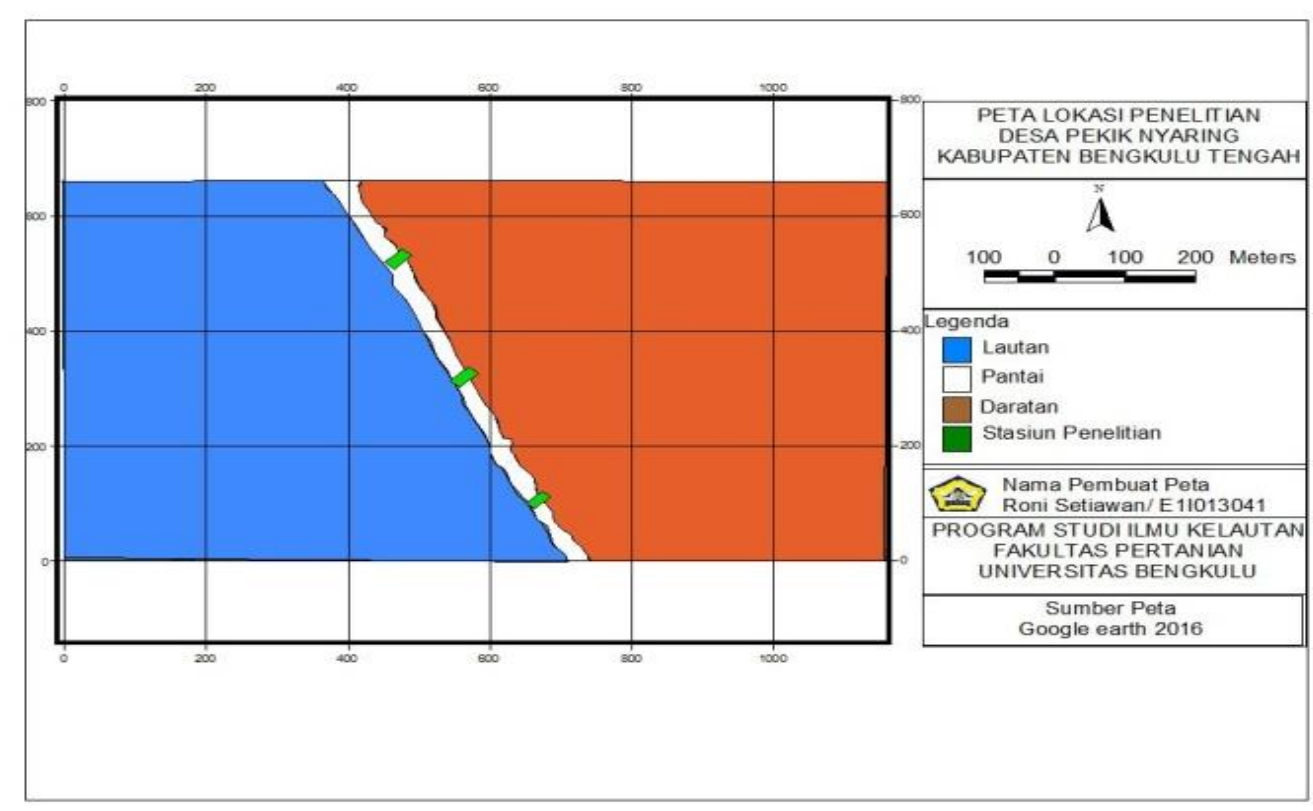

Gambar 1. Peta lokasi penelitian

\subsection{Prosedur penelitian}

Penelitian ini dilakukan dengan metode survei, meliputi kegiatan observasi lapangan dan pengumpulan data primer. Data kondisi bio-fisik dikumpulkan dengan metode observasi dan pengukuran secara langsung pada 3 stasiun pengamatan. Berbagai data pendukung dikumpulkan dengan metode wawancara terhadap masyarakat di lokasi penelitian. Stasiun pengamatan ditetapkan dengan metode purposive sampling dengan mempertimbangkan kondisi fisik pantai, vegetasi pantai dan tempat penyu pernah mendarat dan bertelur. Jarak antara stasiun adalah $500 \mathrm{~m}$.

Pengukuran panjang dan lebar pantai dilakukan pada setiap stasiun pengamatan. Panjang pantai diukur menggunakan GPS (Geo Positioning System) pada bahu pantai (tengah-tengah) dan sejajar dengan garis pantai. Lebar pantai diukur dari titik surut terendah hingga vegetasi terluar, yang terbagi menjadi lebar intertidal (surut terendah hingga pasang tertinggi) dan lebar supratidal (pasang tertinggi hingga vegetasi terluar).

Suhu substrat lokasi peneluran penyu diukur dengan termometer pada dasar substrat, dengan tiga kali pengulangan pada kedalaman contoh sarang yaitu $40-50 \mathrm{~cm}$. Termometer dibenamkan ke dalam pasir selama kurang lebih 5 menit disetiap stasiun. Kelembaban substrat diukur dengan soil meter dengan menggali pasir $\pm 20-30 \mathrm{~cm}$. Soil meter ditancap kedalam pasir selama 3-5 menit. Data kelembaban dibaca pada displai (layar) soil meter. Kemiringan pantai diukur dengan menggunakan klinometer. 
Tekstur substrat diukur dengan menggunakan sampel yang diambil secara acak di lokasi 2-3 meter dari pasang tertinggi ke arah vegetasi terluar pada kedalaman 5-10 $\mathrm{cm}$ di setiap stasiun pengamatan. Sampel substra dimasukkan kedalam plastik dan diberi label untuk dianalisis guna mendapatkan data ukuran butiran substrat. Penentuan fraksi pasir menggunakan saringan bertingkat (seiving) dan kemudian ditimbang berdasarkan ukuran butiran substrat berdasarkan Skala Wentworth. Pengamatan vegetasi pantai dilakukan dengan roll meter yang ditarik sejajar pantai, kemudian diukur berapa panjang yang ditemukan vegetasi dan tak bervegetasi sehingga dapat diketahui berapa persen pantai bervegetasi dan pantai tak bervegetasi (Marshellyna, 2015).

\subsection{Analisis data}

Data hasil penelitian dianalisis dengan menggunakan metode statistik deksriptif. Khusus untuk substrat lokasi peneluran penyu, sampel substrat dianalisis di Laboratorium Teknik Sipil Universitas Bengkulu. Untuk data persentase vegetasi pantai dihitung dengan menggunakan rumus sebagai berikut :

$$
\text { Persentase vegetasi }=\text { Pantai bervegetasi/Total lebar pantai } \times 100 \%
$$

Tingkat kesesuaian habitat peneluran penyu dianalisis dengan menggunakan metode skoring berdasarkana nilai pembobotan dan skoring setiap parameter bio-fisik seperti pada Tabel 1 berikut ini.

Tabel 1. Pembobotan dan skoring dari parameter bio-fisik

\begin{tabular}{llllll}
\hline Parameter & Kriteria & $\begin{array}{l}\text { Batas } \\
\text { Nilai }\end{array}$ & Bobot & $\begin{array}{l}\text { Nilai } \\
\text { Skor }\end{array}$ & Sumber \\
\hline Suhu & $29-32$ & 3 & & 0,9 & Satriadi (2003) \\
Substrat $\left({ }^{\circ} \mathrm{C}\right)$ & $26-28$ & 2 & 0,3 & 0,6 & \\
& $\leq 26-\geq 32$ & 1 & & 0,3 & \\
Kelembaban & $20-29$ & 3 & & 0,9 & Widiastuti (1998) \\
Substrat $(\%)$ & $30-40$ & 2 & 0,3 & 0,6 & dalam Segara (2008) \\
& $<20->40$ & 1 & & 0,3 & \\
Kemiringan Pantai & $8-16$ & 3 & & 0,45 & \\
$(\%)$ & & & & & Nuitja (1992) \\
& $3-8$ & 2 & 0,15 & 0,30 & \\
Tekstur Pasir & $1 / 8-1 / 2$ & 3 & & 0,15 & \\
$(\mathrm{~mm})$ & & & & 0,45 & \\
& $1 / 4-1 / 2$ & 2 & 0,15 & 0,30 & Khaisu (2014) \\
Vegetasi & $2-1 / 2$ & 1 & & 0,15 & \\
& $\geq 75 \%$ & 3 & & 0,3 & Kementrian Negara \\
& $\geq 50 \%-<$ & 2 & 0,1 & 0,2 & Lingkungan Hidup \\
& $75 \%$ & & & & (2004) \\
\hline
\end{tabular}

Kesesuaian lokasi habitat peneluran penyu ditentukan dengan rumus yang dikemukakan oleh Utoyo et al. (2004) dalam Khasanah (2013), sebagai berikut :

Nilai Skor Hasil Evaluasi = Total skor setiap stasiun/3 x $100 \%$. 
Ada pun kriteria kesesuaian lokasi peneluran penyu adalah sebagai berikut : (1) Nilai 85-100 \% (sesuai; stasiun tidak mempunyai pembatas berarti), (2) 60-84\% (cukup sesuai; stasiun mempunyai pembatas yang bisa ditolerir), dan (3) < $60 \%$ (tidak sesuai; stasiun mempunyai pembatas yang berat).

\section{Hasil dan pembahasan}

\subsection{Data pendaratan penyu di desa Pekik Nyaring}

Wilayah pantai Desa Pekik Nyaring sudah lama diketahui sebagai lokasi pendaratan penyu untuk bertelur. Sebagai upaya melestarikan penyu, masyarakat Desa Pekik Nyaring pada tanggal 9 Mei 2016 berinisiatif mendirikan Kelompok Pelestarian Penyu Alun Utara, dan sudah berhasil menetaskan telur penyu sebanyak 2 kali hingga April 2017. Sudah tercatat beberapa kali pendaratan penyu di pantai Desa Pekik Nyaring sejak Tahun 2016 hingga 2017, seperti ditunjukkan pada Tabel 2 berikut ini.

Tebel 2. Rekaman Pendaratan Penyu di pantai Desa Pekik Nyaring

\begin{tabular}{lllll}
\hline No & Tanggal Pendaratan & Jenis Penyu & Jumlah Induk & Jumlah Telur \\
\hline & Tahun 2016 & & \\
1 & 12 Mei 2016 & Penyu Lekang & 1 Ekor & 100 Butir \\
2. & 14 Mei 2016 & Penyu Lekang & 2 Ekor & 206 Butir \\
3. & 22 Mei 2016 & Penyu Lekang & 1 Ekor & 110 Butir \\
4. & 24 Mei 2016 & Penyu Lekang & 1 Ekor & 115 Butir \\
& Tahun 2017 & & \\
5. & 10 Maret 2017 & Penyu Lekang & 1 Ekor & 100 Butir \\
6. & 7 April 2017 & Penyu Lekang & 2 Ekor & 199 Butir \\
7. & 10 Mei 2017 & Penyu Lekang & 1 Ekor & 120 Butir \\
\hline
\end{tabular}

Sumber : Data Kelompok Pelestari Penyu Alun Utara (2017)

Sebelum adanya kelompok pelestarian penyu masyarakat yang mengambil telur penyu dan dijual begitu saja. Tetapi setelah adanya kelompok pelestarian penyu masyarakat yang menemukan telur penyu akan membawanya ke rumah penetasan dan diganti rugi (dibeli) oleh kelompok untuk ditetaskan. Dengan adanya Pelestarian Penyu maka kesadaran masyarakat untuk ikut berpartisipasi dalam menjaga kawasan pelestarian penyu akan semakin meningkat (Minarti et al., 2013). Pada penelitian ini stasiun pengamatan untuk pengambilan data bio-fisik ditetapkan dengan GPS dimana pernah penyu mendarat dan bertelur (Tabel 3).

Tabel 3. Titik koordinat di lokasi pengambilan sampel

\begin{tabular}{llll}
\hline Stasiun & Latitude & Longitude & Keterangan \\
\hline 1 & $03^{\circ} 44^{\prime} 92^{\prime} 2^{\prime \prime}$ & $102^{\circ} 15^{\prime} 30^{\prime} 1{ }^{\prime}$ & $\begin{array}{l}\text { Pernah ditemukan penyu mendarat tetapi } \\
\text { tidak diketahui jenisnya dan bertelur }\end{array}$ \\
2 & $03^{\circ} 44^{\prime} 59^{\prime} 5^{\prime \prime}$ & $102^{\circ} 15^{\prime} 20^{\prime} 4{ }^{\prime}$ & $\begin{array}{l}\text { Pernah ditemukan penyu sisik mendarat dan } \\
\text { bertelur }\end{array}$ \\
3 & $03^{\circ} 44^{\prime} 21^{\prime} 11^{\prime \prime}$ & $102^{\circ} 15^{\prime} 02^{\prime} 3 ”$ & $\begin{array}{l}\text { Pernah ditemukan penyu sisik dan penyu } \\
\text { lekang mendarat dan bertelur }\end{array}$ \\
\hline
\end{tabular}

\subsection{Panjang dan lebar pantai}

Pantai Pekik Nyaring panjangnya $\pm 4,2 \mathrm{~km}$, yang berbatas dengan Sungai Hitam hingga Pasar Pedati. Khusus kawasan untuk konservasi yang dikelola oleh Kelompok 
Pelestari Penyu Alun Utara $\pm 1.47 \mathrm{~km}$. Lebar Pantai terbagi menjadi 2 yaitu intertidal dan supratidal. Hasil pengukuran lebar pantai dapat dilihat pada Gambar 2.

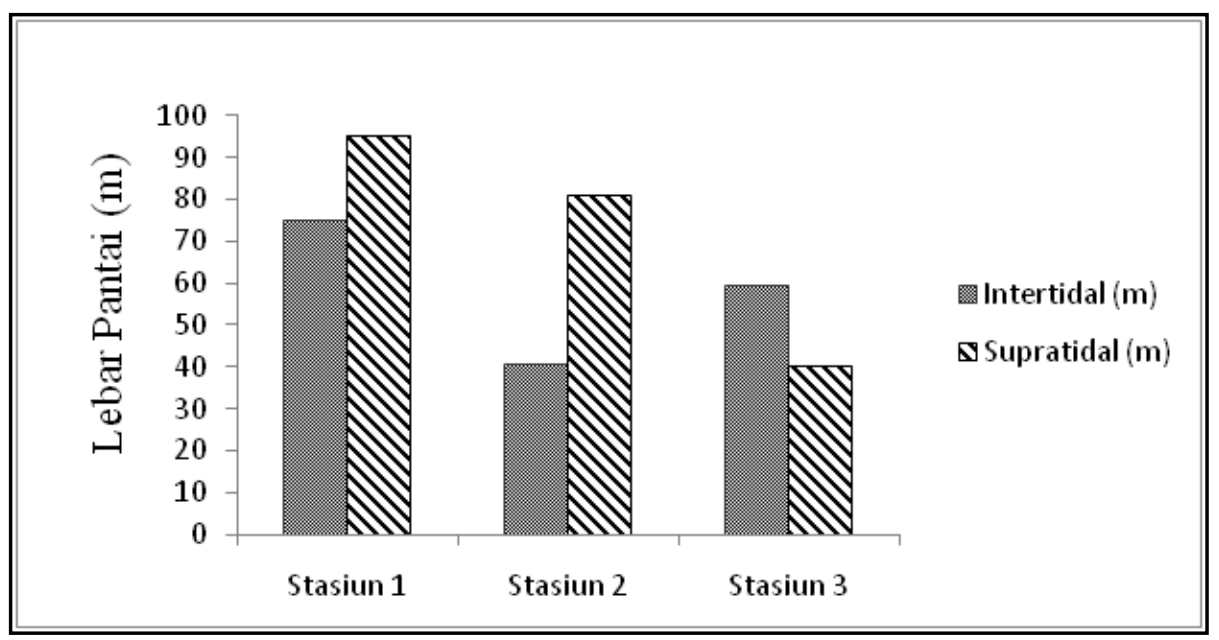

Gambar 2. Hasil pengukuran lebar pantai Pekik Nyaring tempat peneluran penyu

stasiun 1 lebar intertidal $75 \mathrm{~m}$, dan merupakan daerah intertidal terpanjang dibandingkan dengan stasiun lain (Gambar 2). Pada stasiun 2 daerah intertidal hanya 40,6 m sebagai daerah intertidal terendah. Daerah intertidal dipengaruhi oleh pasang tertinggi dan kelandaian suatu daerah tersebut. Daerah supratidal tertinggi pada stasiun 1 yaitu 95 m dan terendah 40,3 m pada stasiun 3. Kikukawa et al., (1999) dalam Catur et al (2011), menyebutkan bahwa lebar pantai berkorelasi baik dengan luas tempat yang tersedia untuk penyu bersarang.

Lebar pantai peneluran penyu yang tergolong ke dalam lebar yang disukai penyu berada pada kisaran $30 \mathrm{~m}-80 \mathrm{~m}$ (Nuitja, 1992 dalam Khaisu, 2014). Berbeda dengan lebar Pantai Pekik Nyaring dengan lebar keseluruhan stasiun 1 adalah 170 m, stasiun 2 adalah 121,4 $\mathrm{m}$ dan stasiun 3 adalah 99,9 m tetapi masih menjadi tempat pendaratan penyu. Menurut Agustina et al. (2010), lebar dan kemiringan pantai juga sangat berpengaruh pada penyu yang mendarat dan membuat sarang.

\subsection{Suhu substrat}

Suhu substrat hari pertama pada stasiun 1 , pagi hari (jam 06.00) adalah $27^{\circ} \mathrm{C}$, hari kedua dan ketiga masing-masing $29^{\circ} \mathrm{C}$. Pada siang hari terjadi kenaikan suhu hingga $30{ }^{\circ} \mathrm{C}$ pada hari ke 2, tetapi pada pukul 24.00 terjadi penurunan suhu hingga 26 ${ }^{\circ} \mathrm{C}$, karena ada hujan. Pada stasiun 1 Suhu substrat rata-rata $28^{\circ} \mathrm{C}$, stasiun 2 rata-rata $28,66{ }^{\circ} \mathrm{C}$ terjadi pada siang hari atau pukul 12.00. Pada hari ke 2 perubahan suhu hingga $39^{\circ} \mathrm{C}$, tetapi pada pagi dan malam hari tidak terjadi fluktuasi yang signifikan. Suhu pada stasiun 3 pada pukul 06.00 pagi yaitu $26^{\circ} \mathrm{C}$. Suhu tertinggi pada hari kedua pukul 12.00 siang yaitu $38{ }^{\circ} \mathrm{C}$ dan $30{ }^{\circ} \mathrm{C}$. Pada hari ketiga, kenaikan suhu sarang dipengaruhi oleh sinar matahari dan kurangnya tutupan vegetasi pada areal tersebut.

Perbedaan suhu pada tiap sarang dipengaruhi oleh banyak sedikitnya intensitas cahaya yang diterima permukaan sarang karena kalor akan diserap dan dirambatkan kepermukaan pasir yang lebih dalam dan sebagian akan dipantulkan (Rofiah et al., 2010). Keadaan suhu substrat sangat berpengaruh terhadap penetesan telur penyu. Yusuf (2000) mengemukakan, bila suhu kurang dari $29^{\circ} \mathrm{C}$, maka sebagian besar adalah tukik jantan, sebaliknya bila suhu lebih dari $29^{\circ} \mathrm{C}$, maka yang akan menetas adalah 
sebagian besar tukik betina. Menurut Lori et al. (2000) dalam Catur et al. (2011), makroklimak akan berpengaruh terhadap mikroklimak (suhu dan kelembapan) sarang, peningkatan suhu akan menginduksi penguapan dan selanjutnya berdampak menurunnya kelembapan sarang.

Data menunjukkan bahwa penyu cenderung mendarat dan bertelur pada malam menuju pagi hari karena suhu dianggap stabil. Menurut Ackerman (1997) dalam Zakyah (2016), pertukaran gas sangat penting untuk mendukung aktivitas metabolisme pada embrio yang berkembang. Batas kisaran bagi perkembangan embrio selama masa inkubasi adalah antara $25-27{ }^{\circ} \mathrm{C}$ dan $33-35{ }^{\circ} \mathrm{C}$. Perubahan $1{ }^{\circ} \mathrm{C}$ dalam kisaran suhu 26$32{ }^{\circ} \mathrm{C}$ dapat menambah atau mengurangi periode inkubasi selama 5 hari.

\subsection{Kelembaban substrat}

Kelembaban substrat merupakan parameter yang berperan dalam masa inkubasi atau penetasan telur penyu, sedangkan media pasir mempunyai kemampuan menyimpan air sebesar 30\%-40\% dengan daya penyimpanan air efektif sebesar $20 \%$ (Widiastuti 1998 dalam Segara, 2008). Semakin tinggi (>40\%) telur akan membusuk dan jika kurang $(<20 \%)$ maka telur akan keriput.

Pada stasiun 1 terjadi peningkatan kelembaban dari hari ke-1 hingga ke-3 dengan waktu yang berbeda. Pada pukul 06.00 terjadi kenaikan kelembaban $29 \%$ dari hari ke-1, $40 \%$ hari ke-2 dan terus meningkat hingga $46 \%$ pada hari ke-3. Peningkatan juga terjadi pada hari yang berbeda. Kelembaban tertinggi 52\% terjadi pada pukul 12.00 hari ke-2. Fluktuasi kelembaban substrat pada stasiun 2 tidak terlalu tinggi. Pada pukul 06.00 kelembaban tertinggi pada hari ke-1 29\% dan terendah hanya $26 \%$. Pada hari ke-2 pukul 12.00 terendah hanya 25\%, sedangkan pada hari ke-3 kelembaban meningkat $33 \%$. Fluktuasi kelembaban yang terjadi di stasiun 2 dapat ditolerir karena tidak melebihi $40 \%$ kadar air. Nilai kelembaban substart pada stasiun 2 ini sangat sesuai dengan tempat penetasan alami telur penyu.

Pada stasiun 3 diketahui bahwa pada hari ke-1 kelembaban tertinggi hanya 55\% yang terjadi pada pukul 24.00. Namun hari ke- 2 terus meningkat $72 \%$ terjadi pada pukul 24.00. Pada hari ke-3 pukul 06.00 hingga pukul 24.00 kelembapan lebih dari $80 \%$ atau melebihi dari sensitifitas alat ukur yang digunakan. Nilai kelembaban pada stasiun 3 ini tidak sesuai dengan kelembaban yang seharusnya untuk penetasan telur penyu, karena sudah melewati batas maksimum. Terjadinya kenaikan kelembapan yang sangat signifikan karena pengaruh pasang air laut. Hitchins, et al., (2003) dalam Catur et al., (2011) menyatakan bahwa tingkat kelembaban pasir dalam sarang dan tingginya pasang terkait dengan pemilihan tempat bertelur. Penyu menyukai pantai yang landai namun penyu juga menyukai kelembaban pasir yang kecil dan cenderung kering.

\subsection{Kemiringan pantai}

Stasiun 1 kemiringan daerah intertidal $1,38 \%$ dan terus meningkat hingga ke daerah vegetasi 3,05\% dengan rata-rata kemiringan 2,22\%. Berbeda dengan stasiun 2 pada daerah intertidal dan supratidal kemiringannya $2,77 \%$ dan menurun $1,38 \%$ pada daerah vegetasi, jika dirata-ratakan kemiringan pada stasiun 2 yaitu 2,31\%. Sedangkan pada stasiun 3 dikategorikan datar karena pada daerah intertidal hingga vegetasi jika dirata-ratakan hanya 0,85\%. Hasil kajian Hartono et al., (2016), adapun wilayah yang tingkat kelerengannya rata-rata 5\% terletak di wilayah kecamatan Pondok Kelapa (termasuk Desa pekik Nyaring), dengan daerah terendah terletak di wilayah Kecamatan Pondok Kelapa dengan ketinggian 0 - 15 m dpl. Menurut Nuitja (1992) kondisi pantai 
yang landai (3-8\%) dan miring (8-16\%) sesuai bagi habitat peneluran penyu, karena kondisi landai tersebut dapat memudahkan penyu untuk mencapai tempat peneluran.

Berdeda dengan Pantai Pekik Nyaring yang bertipe datar tetapi masih sering dijumpai penyu untuk bertelur, hal terlihat pada logbook Kelompok Pelestari Penyu Alun Utara. Hal ini sangat sesuai dengan semua jenis penyu yang mendarat untuk bertelur yang dalam 3 stasiun tersebut dalam kategori datar.

Kemiringan pantai yang disukai penyu adalah pantai landai, karena sangat berpengaruh pada aksebilitas penyu untuk mencapai daerah yang cocok untuk bertelur. Semakin curam pantai maka besar pula energi yang diperlukan untuk menuju supratidal untuk melakukan peneluran serta semakin sulit penyu ketika melihat objek yang berada di depannya, karena mata penyu hanya mampu melihat dengan baik dengan sudut dibawah $150^{\circ}$ (Yusuf, 2000). Hasil Penelitian Khaisu (2014) di Taman Wisata Alam (TWA) Air Hitam Bengkulu, menjelaskan bahwa pantai yang terdapat pada lokasi tersebut dikategorikan datar dengan sudut kemiringan $0,97-4,23^{\circ}$, jika dipresentasekan hanya $0,26-1,17 \%$. Tipe pantai ini sama dengan tipe pantai di pantai Pekik Nyaring.

\subsection{Tekstur substrat}

Substrat merupakan media untuk meletakkan telur penyu yang umumnya berpasir. Kandungan pasir akan cepat menyerap panas pada siang hari akibat sinar matahari dan akan lama menyimpan suhu hangat yang berfingsi dalam masa inkubasi telur penyu. Hasil analisis fraksi pasir pada substrat peneluran penyu di pantai Pekik Nyaring menunjukaan bahwa fraksi pasir di pantai Pekik Nyaring dari stasiun 1 hingga stasiun 3 keseluruhannya (100\%) adalah berupa pasir halus. Menurut Utomo (2005) dalam Khaisu (2014) karakteristik pantai yang dipilih penyu lekang (L. olivacea) sebagai tempat bertelur adalah pantai berpasir halus dengan hamparan yang luas dan landai serta substrat pasir yang berwarna gelap. Mortimer (1990) dalam Catur et al., (2011) menambahkan pasir kasar yang kering membuat induk penyu betina sulit menggali untuk membuat sarang. Dan menurut Nybakken (1992) dalam Satriadi et al., (2003), bahwa tekstur kasar bersifat lebih mengalirkan air dari pada menampung air karena pasir bertekstur kasar memiliki pori yang lebih besar.

\subsection{Vegetasi pantai}

Keberadaan vegetasi pantai merupakan karakteristik biologi yang mempengaruhi penyu dalam menentukan lokasi untuk bertelur. Sepanjang pantai Desa Pekik Nyaring umumnya didominasi oleh cemara laut dan katang-katang. Sesuai dengan pernyataan dari Hartono et al (2014), bahwa di kawasan pantai Desa Pekik Nyaring jenis vegetasi yang tumbuh adalah cemara, kelapa, ketapang (ditanam) dan katang-katang (Ipomoea pescaprae).

Vegetasi berfungsi menjaga kesetabilan suhu agar tidak terjadi kenaikan suhu yang terlalu tinggi, yang disebabkan oleh sinar matahari. Vegetasi juga berfungsi sebagai penjaga telur penyu dari predator (binatang buas) (Hermawan et al., 1993). Akan tetapi jenis tumbuhan yang merayap di atas pantai seperti rumput (Spinifex littoralls) dari formasi Ipomoea pes-caprae, sangat mengganggu aktivitas peneluran penyu laut, yaitu mengganggu penggalian sarang di pantai (Priyono, 1989).

Spesies vegetasi yang terdapat di pantai Pekik Nyaring adalah Cemara Laut (Casuarina equisetifolia), Biduri (Calotropis gigantea), Katang-katang (Ipomoea pescaprae), Wedelia (Sphagneticola trilobata), Rumput tali putri (Cassytha filiformis L.) dan Rumput Gajah (Pennisetum purpureum). Suwondo dan Hendri (2004) dalam 
Roemantyo et al (2012) melaporkan bahwa pada pantai dengan kemiringan lebih besar dari $30 \%$ naungan vegetasi terhadap sarang cenderung mempengaruhi kelembaban sarang.

Pada stasiun 1 persentase vegetasi 50,8\% dengan 2 spesies yaitu cemara laut dan katang-katang. Stasiun 2 terdapat 6 spesies vegetasi dengan presentase vegetasi tertinggi $60,3 \%$. Stasiun 3 dengan presentase vegetasi terendah yaitu $22,3 \%$ karena stasiun ini memiliki daerah intertidal lebih lebar dibandingkan daerah supratidal.

\subsection{Analisis kesesuaian}

Hasil analisis skoring data bio-fisik lokasi pengamatan habitat peneluran penyu di Desa pekik Nyaring (Tabel 4).

Tabel 4. Hasil skoring pembobotan parameter bio-fisik

\begin{tabular}{|c|c|c|c|c|c|c|c|}
\hline Parameter & Stasiun & $\begin{array}{l}\text { Hasil } \\
\text { Pengukuran }\end{array}$ & Kriteria & \multicolumn{2}{|c|}{ Batas Nilai } & \multirow[t]{2}{*}{ Bobot } & $\begin{array}{l}\text { Nilai } \\
\text { Skor }\end{array}$ \\
\hline Suhu & 1 & 28 & $26-28$ & 2 & $\begin{array}{l}\text { Cukup } \\
\text { Sesuai }\end{array}$ & & 0,6 \\
\hline \multirow[t]{2}{*}{ Substrat $\left({ }^{\circ} \mathrm{C}\right)$} & 2 & 28,66 & $29-32$ & 2 & $\begin{array}{l}\text { Cukup } \\
\text { Sesuai }\end{array}$ & \multirow[t]{3}{*}{0,3} & 0,6 \\
\hline & 3 & 28,66 & $29-32$ & 2 & $\begin{array}{l}\text { Cukup } \\
\text { Sesuai }\end{array}$ & & 0,6 \\
\hline Kelembapan & 1 & 40,44 & $<20->40$ & 2 & $\begin{array}{l}\text { Cukup } \\
\text { Sesuai }\end{array}$ & & 0,6 \\
\hline \multirow[t]{2}{*}{ Substrat (\%) } & 2 & 28,77 & $20-29$ & 3 & Sesuai & \multirow[t]{3}{*}{0,3} & 0,9 \\
\hline & 3 & 66 & $<20->40$ & 1 & $\begin{array}{l}\text { Tidak } \\
\text { Sesuai }\end{array}$ & & 0,3 \\
\hline $\begin{array}{l}\text { Kemiringan } \\
\text { Pantai }\end{array}$ & 1 & 2,22 & $<3->16$ & 1 & $\begin{array}{l}\text { Tidak } \\
\text { Sesuai }\end{array}$ & & 0,15 \\
\hline$(\%)$ & 2 & 2,31 & $<3->16$ & 1 & $\begin{array}{l}\text { Tidak } \\
\text { Sesuai }\end{array}$ & \multirow[t]{2}{*}{0,15} & 0,15 \\
\hline \multirow{4}{*}{ Fraksi Pasir } & 3 & 0,85 & $<3->16$ & 1 & $\begin{array}{l}\text { Tidak } \\
\text { Sesuai }\end{array}$ & & 0,15 \\
\hline & 1 & $100 \%$ & $1 / 8-1 / 2$ & 3 & Sesuai & \multirow{3}{*}{0,15} & 0,45 \\
\hline & 2 & $100 \%$ & $1 / 8-1 / 2$ & 3 & Sesuai & & 0,45 \\
\hline & 3 & $100 \%$ & $1 / 8-1 / 2$ & 3 & Sesuai & & 0,45 \\
\hline \multirow[t]{3}{*}{ Vegetasi (\%) } & 1 & 50,8 & $\begin{array}{l}\geq 50 \%- \\
\leq 75 \%\end{array}$ & 2 & $\begin{array}{l}\text { Cukup } \\
\text { Sesuai }\end{array}$ & \multirow{3}{*}{0,1} & 0,2 \\
\hline & 2 & 60,3 & $\begin{array}{l}\geq 50 \%- \\
\leq 75 \%\end{array}$ & 2 & $\begin{array}{l}\text { Cukup } \\
\text { Sesuai }\end{array}$ & & 0,2 \\
\hline & 3 & 22,3 & $<50 \%$ & 1 & $\begin{array}{l}\text { Tidak } \\
\text { Sesuai }\end{array}$ & & 0,1 \\
\hline
\end{tabular}


ISSN 2620-570X

JURNAL ILMU KELAUTAN KEPULAUAN, 1 (1) ; 59 - 70, JUNI 2018

Tabel 5. Analisis kesesuain habitat peneluran penyu

\begin{tabular}{llllllll}
\hline $\begin{array}{l}\text { Stasiu } \\
\mathrm{n}\end{array}$ & Suhu & $\begin{array}{l}\text { Kelembaba } \\
\mathrm{n}\end{array}$ & $\begin{array}{l}\text { Kemiringa } \\
\mathrm{n}\end{array}$ & $\begin{array}{l}\text { Fraks } \\
\mathrm{i}\end{array}$ & $\begin{array}{l}\text { Vegetas } \\
\mathrm{i}\end{array}$ & $\begin{array}{l}\text { Nilai } \\
\text { Evaluas } \\
\mathrm{i}\end{array}$ & $\begin{array}{l}\text { Keteranga } \\
\mathrm{n}\end{array}$ \\
\hline 1 & 0,6 & 0,6 & 0,15 & 0,45 & 0,2 & $66,6 \%$ & $\begin{array}{l}\text { cukup } \\
\text { Sesuai } \\
\text { cukup } \\
\text { Sesuai }\end{array}$ \\
2 & 0,6 & 0,9 & 0,15 & 0,45 & 0,2 & $76,6 \%$ & $\begin{array}{l}\text { Pabstrat } \\
\text { Tidak } \\
3\end{array}$ \\
\hline
\end{tabular}

Hasil analisis kesesuaian lokasi untuk tempat penyu bertelur (Tabel 5). Nilai skor hasil evaluasi parameter biofisik untuk stasiun 1 dan stasiun 2 menunjukkan hasil cukup sesuai untuk lokasi habitat peneluran penyu, artinya stasiun 1 dan stasiun 2 mempunyai pembatas yang bisa ditolerir. Hal ini dikarenakan beberapa parameter yang menjadi faktor pembatas untuk lokasi peneluran penyu seperti, kemiringan pantai dan vegetasi berada pada batas nilai skor terendah akan tetapi pada parameter suhu substrat, kelembapan substrat dan tekstur substrat tidak melebihi batas optimal. Pada stasiun 3 hasil evaluasi tidak sesuai sehingga stasiun ini mempunyai pembatas yang berat. Hal ini dikarenakan terdapat beberapa parameter yang hanya masuk dalam kriteria seperti suhu dan substrat dengan batas nilai cukup sesuai dan tekstur pasir pada batas nilai sesuai, dan 3 parameter lainnya seperti kemiringan pantai, kelembaban substrat dan vegetasi pantai yang tidak masuk dalam kriteria.

\section{Kesimpulan}

Zona peneluran penyu di pantai Pekik Nyaring meliputi panjang 1,47 km dan lebar 99,9-170 m. Kemiringan pantai masuk kategori datar yaitu 0,85-2,22 \%. Suhu habitat peneluran penyu $28^{\circ} \mathrm{C}$ pada stasiun 1 , dan $28,66^{\circ} \mathrm{C}$ pada staisun 2 dan stasiun 3. Kelembaban substrat stasiun 1 rata-rata $40,44 \%$, stasiun 2 rata-rata $28,77 \%$ dan stasiun 3 rata-rata $66 \%$. Fraksi pasir semua stasiun masuk kategori halus mencapai 100 $\%$. Vegetasi dominan adalah cemara laut (untuk pohon), biduri (untuk tiang dan pancang). Tumbuhan bawah atau tumbuhan merambat adalah katang-katang, wedelia, rumput tali putri dan rumput gajah. Lokasi pengamatan stasiun 1 dan stasiun 2 menunjukkan kategori cukup sesuai sebagai lokasi peneluran penyu, sedangkan stasiun 3 kategori tidak sesuai karena terdapat beberapa parameter yang tidak masuk kriteria.

\section{Daftar Pustaka}

Ageng, M., Wicaksono, Elfidasari, D., dan Kurniawan, A. 2013. Aktivitas pelestarian penyu hijau (Chelonia mydas) di Taman Pesisir Pantai Penyu Pangumbahan Sukabumi Jawa Barat. Program Studi Biologi Fakultas Sains dan Teknologi Universitas Al Azhar Indonesia, Jakarta.

Agustina, R. P., Iskandar, dan S. Alisyahbana, H. 2010. Hubungan perubahan garis pantai terhadap habitat bertelur penyu hijau (Chelonia mydas) di Pantai Pangumbahan Ujung Genteng, Kabupaten Sukabumi. Jurnal Perikanan dan Kelautan Vol. 3. September 2012:311-320 
Bappeda Kabupaten Bengkulu Tengah. 2013. Rencana Induk Pengembangan Kawasan Minapolitan Kabupaten Bengkulu Tengah. Bappeda Kabupaten Bengkulu Tengah.

Bappeda Provinsi Bengkulu. 2016. Dokumen Rencana Pembangunan Jangka Menengah Daerah (RPJMD) 2016-2021 Provinsi Bengkulu.

Catur, S., Setyawanitiningsih, Marniasih, D. dan Wijayanto. 2011. Karakteristik biofisik tempat peneluran penyu sisik (Eretmochelys Imbricata) di Pulau Anak Ileuh Kecil, Kepulauan Riau. Jurnal Teknobiologi: II(1) 17-22

Dahuri. R.. 2003. Keanekaragaman hayati laut. PT Gramedia Pustaka Utama, Jakarta.

Dermawan, A., Antong, Wahyu W., Mutiaratih dan S. Khadijah. 1999. Annual Report (1998-1999): Hatching, rearing, releasing and tagging Programme of Hawksbill Turtle in Indonesia. A Collaboration Between Directorate General of Nature Protection and Conservation Ministry of Forestry and Estate Crops Republic of Indonesia and Japan Bekko Association. Jakarta.

Hartono, D., Zamdial Ta'alidin, Deddy Bakhtiar dan Eko Nofridiansyah. 2014. Laporan akhir identifikasi kerusakan daerah pesisir Provinsi Bengkulu. Dinas Kelautan dan Perikanan Provinsi Bengkulu, Bengkulu.

Hartono, D., Zamdial Ta'alidin dan Zulman Efendi. 2016. Laporan akhir kegiatan penyusunan roadmap pembangunan industri berbasis kemaritiman dan perikanan Kabupaten Bengkulu Tengah. Badan Perencanaan Pembangunan Daerah (Bappeda) Pemerintah Kabupaten Bengkulu Tengah.

Hermawan D., Saddon S., dan H. Muhammad E. 1993. Studi habitat peneluran penyu sisik (Eretmochelys imbricata L) Di Pulau Peteloran Timur dan Barat Taman Nasional Kepulauan Seribu. Jurnal Ilmu-ilmu Perairan dan Perikanan Indonesia. I(1) No.33-37

IUCN, 2008. The IUCN Red List of Threatened Species. London (GB): IUCN SSC Marine Turtle Specialist Group.

Kementerian Negara Lingkungan Hidup. 2004. Keputusan Menteri Negara Lingkungan Hidup Nomor : 201 Tahun 2004 tentang Kriteria Baku Mutu dan Pedoman Penentuan Kerusakan Mangrove.

Khaisu, M.S. 2014. Karakteristik habitat peneluran penyu lekang (Lepidochelys olivecea, Hirth 1971) di Taman Wisata Alam Air Hitam, Bengkulu. Departemen Ilmu dan Teknologi Kelautan Fakultas Perikanan dan Ilmu Kelautan Institut Pertanian Bogor. Bogor.

Khasanah, U. 2013. Analisis kesesuaian perairan untuk lokasi budidaya rumput laut eucheuma cottonii di Perairan Kecamatan Sajoanging Kabupaten Wajo. Skripsi. Jurusan Ilmu Kelautan Fakultas Ilmu Kelautan dan Perikanan Universitas Hasanuddin. Makasar.

Marshellyna, F. L. 2015. Karakteristik kondisi bio-fisik pantai tempat peneluran penyu di Pulau Mangkai Kabupaten Kepulauan Anambas Provinsi Kepulauan Riau. Ilmu Kelautan.FIKP UMRAH. Kepulauan Riau

Minarti, I. H., A. Fahrudin, dan Yusli W. 2013. Pengelolaan kolaboratif kawasan konservasi penyu Pangumbahan Kabupaten Sukabumi. Jurnal Ilmu Pertanian Indonesia (JIPI), April 2015 Vol.20 (1): 39-46

Nuitja, I.N.S. 1992. Biologi dan ekologi pelestarian penyu laut. IPB Press, Bogor. 127 hlm. 
Priyono A., 1989. Pengelolaan habitat dan satwa penyu laut. Media Konservasi Vol.II (2) Januari $1989: 33-38$

Roemantyo A. Sri Nastiti, dan Ngurah N. Wiadnyana. 2012. Sturktur dan komposisi vegetasi sekitar sarang penyu hijau (Chelonia mydas Linnaeus) Pantai Pangumbahan, Sukabumi Selatan, Jawa Barat. Berita Biologi 11(3)-Desember 2012

Rofiah A. Retno H. dan Edi W. 2010. Pengaruh naungan sarang terhadap persentase penetasan telur penyu lekang (Lepidochelys olivacea) di Pantai Samas Bantul, Yogyakarta. Jurnal Of Marine Research. Volume 1, Nomor 2, Tahun 2012, Halaman 103-108

Satriadi A., Esti R., dan Nurul A. 2003. Identifikasi penyu dan studi karakteristik fisik habitat penelurannya di Pantai Samas, Kabupaten Bantul, Yogyakarta. Jurnal Ilmu Kelautan Vol.8 (2) : 69-75

Segara, A.R., 2008. Studi karakteristik biofisik habitat peneluran penyu hijau (chelonia mydas) di Pangumbahan Suka Bumi, Jawa barat. Skripsi. Program Studi Ilmu dan Teknologi Kelautan Fakults Pertanian dan Ilmu Kelautan Institut Pertanian Bogor. Bogor.

Yayasan Alam Lestari, 2000. Mengenal penyu.Yayasan Alam Lestari dan Keidanren Nature Conservation Fund (KNCF) Jepang. 81 hal.

Yulmeirina, Thamrin, dan Nasution, S., 2016. Habitat karakteristics nesting environment of hawksbill turtle (Eretmochelys imbricata) in the East $\mathrm{Yu}$ Island Of Thousan Island National Park. Lecturer at the Faculty of Fisheries and Marine Sciences, Universitas of Riau. Riau.

Yusuf, A. 2000. Mengenal penyu. Yayasan alam lestari. Jakarta.

Zakyah, 2016. Pengaruh struktur terhadap tingkat keberhasilan penetasan telur penyu hijau ( Chelomia mydas L.) serta pemanfaatannya sebagai Buku Ilmiah Populer. Program Studi Pendidikan Biologi Jurusan Pendidikan MIPA Fakultas Keguruan dan Ilmu Pendidikan Universitas Jember. 